\title{
Review
}

\section{Koschei the immortal and anti-aging drugs}

\author{
MV Blagosklonny ${ }^{*, 1}$
}

In Slavic folklore, Koschei the Immortal was bony, thin and lean. Was his condition caused by severe calorie restriction (CR)? CR deactivates the target of rapamycin pathway and slows down aging. But the life-extending effect of severe CR is limited by starvation. What if Koschei's anti-aging formula included rapamycin? And was rapamycin (or another rapalog) combined with commonly available drugs such as metformin, aspirin, propranolol, angiotensin II receptor blockers and angiotensin-converting enzyme inhibitors.

Cell Death and Disease (2014) 5, e1552; doi:10.1038/cddis.2014.520; published online 4 December 2014

\section{Facts}

- Calorie restriction deactivates mTOR and increases life span

- Rapamycin prevents obesity and extends life span

- In fairy tales, long-lived heroes were lean, slim and bony

\section{Open Questions}

- Were their leanness and longevity due to genetic inhibition of mTOR?

- Can leanness plus longevity be achieved by rapamycin?

- How to combine five clinically available anti-aging drugs with calorie restriction?

Koschei the deathless (a villain in Russian, Polish and Ukrainian fairy tales) was immortal, strong, bony and lean (Figure 1). Was it his passion for the young princess Vassilisa, the Beautiful, who rendered him immortal? Did he lose his appetite because of his tragic love? Or was he secretly taking a rapalog such as rapamyin (Sirolimus), Temsirolimus, Everolimus and Deforolimus. And did Koschei benefit from benevolent glucose intolerance? Or, in contrast, was he insulin hypersensitive? Here are some answers and subsequent questions.

\section{Rapamycin Prevents Obesity}

In mice on high-fat diet, rapamycin decreases obesity and prevents weight gain. ${ }^{1-4}$ In rats, rapamycin (3 times per week) decreased age-associated weight gain. ${ }^{5}$ Also, chronic (everyday) treatment with rapamycin reduces adiposity and body weight. $^{6,7}$ (In some strains, chronic daily treatment was associated with insulin resistance (IR), but more on that latter). In humans, rapamycin decreases the size of fat cells (adipocytes) and body weight. ${ }^{5}$ In humans, kidney transplantation is associated with weight gain, which is preventable by rapamycin. ${ }^{8}$ So, at least at high doses, rapamycin can decrease weight gain in mice, rats and humans. Yet, Koschei was unusually skinny and there is no data that rapamycin can cause such a severe weight loss.

\section{How Rapamycin Prevents Obesity}

a. Rapamycin increases lypolysis, releasing fatty acids from the fat tissue..$^{9-12}$

b. Rapamycin prevents entry of lipoproteins into the tissues. ${ }^{6}$

c. Rapamycin decreases insulin secretion, therefore, preventing insulin-induced obesity. ${ }^{13}$

d. Rapamycin prevents adipocyte differentiation. ${ }^{10,14-16}$

Rapamycin increases lipolysis and decreases, this can lead to hyperlipidemia (see for explanation schema $2 \mathrm{in}^{17}$ ). Hyperlipidemia (or dyslipidemia) is a biomarker of the treatment with high doses of rapamycin and evirolimus. ${ }^{9}$ Rapalog-induced dyslipidemia is a benevolent sign of therapeutic effects. In fact, rapamycin prevents atherosclerosis. ${ }^{18-20}$

Hyperlipidemia is rapidly reversible. ${ }^{21}$ Eventually, hyperlipidemia disappears despite chronic use of rapamycin. ${ }^{22}$ Noteworthy, hyperlipidemia can be diminished by lipidlowering drugs, as shown in renal transplant patients who were receiving rapamycin. ${ }^{23}$

Fatty acids are burned by the muscles (especially during physical exercise) and also incorporated into lipoproteins by the liver.

We can hypothesize that benevolent dyslipidemia can be diminished by the following:

a. Physical exercise (the muscle burns lipids).

b. Calorie restriction.

These two predictions need to be tested. 


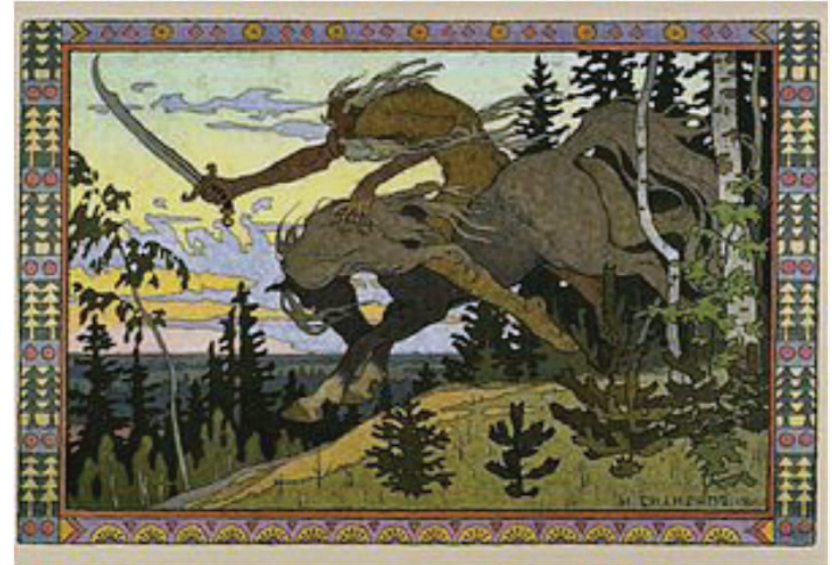

Figure 1 Koshchey the Deathless by Ivan Bilibin, 1901

mTOR Causes Obesity and IR. Mammalian target of rapamycin (mTOR) is a nutrient-sensing pathway. ${ }^{24-31}$ Nutrients such as glucose, amino and fatty acids activate mTOR and also increase insulin, which also activates mTOR. In the fat tissue, mTOR promotes adipocyte differentiation and hypertrophy, increases lipogenesis (synthesis of triglycerids) and decreases lipolysis (hydrolysis of triglycerides), leading to fat accumulation or obesity. In a vicious cycle, obesity activates mTOR. ${ }^{32,33}$

To limit its overactivation, mTOR blocks insulin signaling, causing IR. ${ }^{34-39}$ Rapamycin and calorie restriction (CR) can reverse $I_{R} .^{32,34,40-49}$ For example, in healthy men, infusion of amino acids activates mTOR causing IR. ${ }^{44,46}$ Administration of $6 \mathrm{mg}$ rapamycin before amino acids prevents IR. ${ }^{46}$ Noteworthy, IR and metabolic syndrome are multifactorial. ${ }^{50-61}$

\section{The Misunderstood Effect: Benevolent IR}

The most common argument against rapamycin is that it causes IR. Somehow, this is the only rumor that many scientists heard about rapamycin. In fact, glucose intolerance and IR was observed in a few strains of rodents treated daily with high doses of rapamycin. ${ }^{2,62-64}$ Yet, this was not detrimental for animal health. In contrast, IR was associated with weight loss and/or extended life span. Furthermore, unlike C57BL/6 mice, ${ }^{64}$ genetically heterogeneous HET3 mice on a rapamycin diet were glucose intolerant but insulin sensitive. ${ }^{65}$ Ironically, although believing that rapamycin is dangerous, most scientists do not know the difference between glucose intolerance and IR. They know even less about classic conditions of spectacular glucose intolerance and IR. Claude Bernard (19th century) described that during starvation humans and dogs develop reversible starvation-diabetes. ${ }^{66}$ If a starved animal (or human) consumes sugar, this sugar will appear in the urine, forcing water to follow (polyuria). The word 'diabetes' means an increased amount of urine (polyuria). And 'mellitus' means sweet. This sweet taste had been noticed in the urine by the ancient Greeks. So starvation is accompanied by the most definitive symptom of 'diabetes mellitus'. This is a reversible condition to cope with starvation.

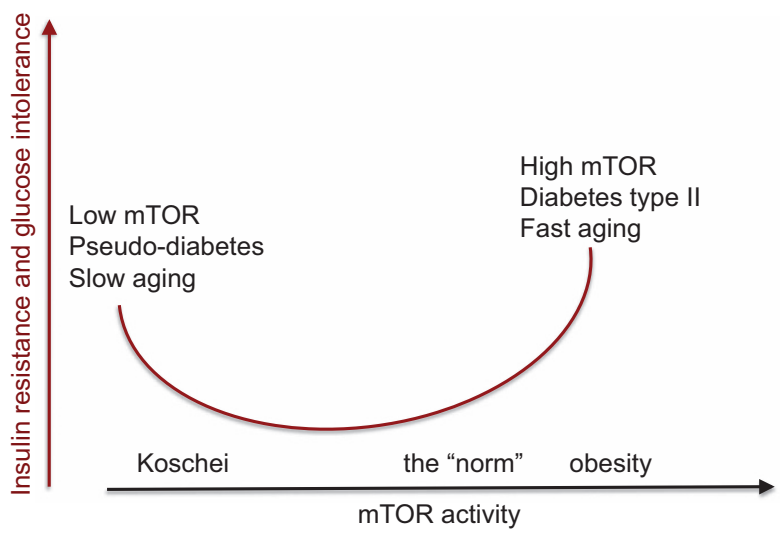

Figure 2 Insulin-resistance: two opposite conditions. Insulin resistance (IR) can be caused by the activation of mTOR and, paradoxically, by mTOR inhibition. In the first case, $\mathbb{R}$ is detrimental for health, whereas in the second case it is benevolent $^{13,66,67}$

\section{Why Starvation Is Manifested by Benevolent Pseudodiabetes?}

During fasting, lipolysis is increased providing the 'fuel' (free fatty acids and glycerol) for the peripheral tissues. The brain depends on glucose (and ketones). In the liver, amino acids are converted into glucose (gluconeogenesis) and fatty acid into ketones. To spare glucose for the brain, insulin secretion is inhibited and peripheral tissues become insulin resistant. Low insulin levels and IR are manifested as glucose intolerance: if a starved person consumes glucose, it is not metabolized by the tissues, its blood levels rose and glucose appears in the urine. Also, the liver produces ketones from lipids (to feed the brain). Production of ketones is a hallmark of type I diabetes. Starvation-induced pseudodiabetes is benevolent because they are associated with inhibited mTOR. ${ }^{67}$ In contrast, in the modern time, IR (as we know it) is associated with obesity and leads to diabetes type II. ${ }^{40,13}$ This harmful IR is associated with over-activation of mTOR and aging (Figure 2).

\section{Calorie Restriction}

CR extends life span in numerous species from worm to mammals. ${ }^{11,28,68-81} \mathrm{CR}$ prevents age-related diseases including cancer and sarcopenia. ${ }^{82-84}$ Whereas moderate CR increases insulin sensitivity, severe CR causes signs of IR. ${ }^{85}$ Among individuals who had been practicing severe CR, $40 \%$ of CR individuals showed 'diabetic-like' glucose intolerance. ${ }^{85}$ In theory, starvation would be beneficial for health, but cannot last long enough for obvious reason - death from starvation. But high doses of rapamycin can mimic severe CR without actual nutrient deficiency, thus lacking harmful effects of starvation.

\section{Koschei Was not Starved}

Definitely, Koschei was not starved. He was bonny and strong and this is not compatible with starvation. Fasting that is manifested by 'diabetes' (sugar in the urine) cannot last too long to extend life span but rapamycin can. And since rapamycin does not decrease food consumption, it may 
extend life span dramatically, while moderately preventing obesity. Importantly, rapamycin increases skeletal muscle and bone mass. ${ }^{86}$ Given that Koschei was deathless, healthy, strong (muscular) and bony, he perhaps used CR-mimetic such as rapamycin, rather than severe CR.

\section{Rapamycin Plus Moderate CR}

Because rapamycin inhibits mTOR but not food consumption, rapamycin is expected to disproportionally increase life span compared with its moderate effects on body weight. For example, at low doses and frequencies, which do not cause IR and other metabolic alterations, rapamycin still extends life span in mice. ${ }^{87}$ As we discussed, acute treatment by rapamycin increases insulin sensitivity. Pulse (intermittent) treatment with rapamycin (either once a week or every other week or intermittent short courses) extends life span, ${ }^{88-93}$ while maintaining insulin sensitivity. ${ }^{87}$ In high-fat diet-fed C57BL/6 mice, weekly rapamycin for 22 weeks improved metabolic and immune status. Rapamycin-treated mice were leaner and were protected against IR and mTORC2 activity was intact. ${ }^{4}$ So, life extension by rapamycin can be associated with either IR or insulin sensitization depending on the dose and the frequency of administration. The life extension and anticancer effects were detectable at low-frequency administration, when little effect on weight was observed. Yet Koschei was extraordinary lean. We can consider two scenarios. First, he might use very high doses of rapamycin to develop 'starvation-like diabetes', which can be followed by weight loss. (Note: weight loss is a symptom of type I diabetes). Although high chronic doses of rapamycin in some strains of mice cause IR, this IR did not reach the magnitude of fullblown 'pseudodiabetes mellitus'. According to second scenario, Koschei combined rapamycin with standard CR (not starvation). We can expect that this will both extend life span and eliminate fat tissue. In agreement with second scenario, Koschei was known to be greedy, so CR was naturally added to rapamycin. And he should not experience diabetic-like polyurea because he did not eat sweets or sugar, but instead his diet consisted from small amount of meat (human), fish (mermaid) and fresh vegetables (nettle).

\section{Once Again on Benevolent IR}

In contrast, starvation/rapamycin-induced IR is associated with inhibited mTOR (Figure 1). In all animal models, IR coupled with low mTOR is associated with health and life span extension. ${ }^{67}$ Is benevolent IR and pseudodiabetes a goal of rapamycin treatment for maximal life span extension? Or, in contrast, this should be avoided? In other words, should we use high doses of rapamycin daily or pulse (intermittent) treatment.

Apart from the question whether rapamycin-induced IR is benevolent or not, it is unclear what is its exact mechanism. In different studies, IR was accompanied either by low or high insulin levels. In some studies, IR was associated with low activation of Akt by insulin, ${ }^{64,94}$ whereas in other studies rapamycin promoted IR despite normal activation of the Akt axis. ${ }^{6}$ In cell culture, rapamycin reverses IR caused by glucose and does not cause IR even at chronic (2 weeks) use. ${ }^{95}$
Thus, details of rapamycin-induced IR are still unclear. What is clear is that at both high and low doses, at chronic and intermittent administrations, rapamycin extends life- and health-span in mice. Also, it was taken by millions of humans in high doses daily, even though transplant and cancer patients were in bad health to start with. The most noticeable side effects of rapalogs (rapamycin, tecrlolimus, everolimus) are prevention of cancer ${ }^{96-98}$ and regression of heart hypertrophy in kidney transplant recipients. ${ }^{99}$ Rapalogs are anticancer drugs. ${ }^{100-109}$

\section{Rapalogs as Anti-aging Drugs}

Nutrients activate mTOR pathway, which drives cellular growth and functions, and then geroconversion and hyperfunctions. ${ }^{110}$ On organismal level, mTOR drives growth early in life and aging later in life. ${ }^{111,112}$ Rapamycin slows aging and extends life span in mice. ${ }^{113-121}$ What is the cellular mechanism that allows rapamycin to slow organismal aging? Rapamycin slows down geroconversion: conversion from quiescence to irreversible senescence. ${ }^{122-130}$ Senescence is characterized by cellular hyperfunction (hyper secretion, hypertrophy, pro-inflammation and so on. ${ }^{131-136}$ This cellular hyperfunction also cause a feedback signal resistance (such as IR) to limit hyperfunctions. A combination of hyperfunctions and signal resistance leads to alterations in homeostasis and initiates age-related diseases such as obesity, atherosclerosis, hypertension, neurodegeneration, osteoporosis, sarcopenia. ${ }^{30,119,137,138}$ Cancer is preventable by rapamycin. ${ }^{88,90,91,96-98,136,139-146}$ Rapamycin prevents age-related diseases in rodents from macular degeneration and obesity to cancer and heart dysfunction. ${ }^{142,146,147-152}$ Rapamycin also extends life span in normal and cancer-prone mice as well as in mice with premature aging syndromes. ${ }^{93,153}$ In the latter case, rapamycin at an average extended life span more $100 \%$ and maximal survival $>300 \%{ }^{153}$

\section{The Anti-aging Formula}

Koschei was constantly fighting with enemies. So physical exercise was a part of his daily life. Mobilized by rapamycin, lipids can be burned by the muscle during physical exercise. By itself, chronic physical exercise inhibits mTOR and increases insulin sensitivity. ${ }^{154}$ Thus, rapamycin was combined with moderate CR (based on vegetables and fish) and physical exercise.

There are several clinically approved, widely used drugs that could be added to the rapamycin CR/exercise combination. They include metformin, aspirin, inhibitors of angiotensin II and propranolol.

It was shown almost 50 years ago that phenformin and metformin, anti-diabetic drugs that improve IR, also slow down aging and prevent cancer in rodents. ${ }^{100,106,155-163}$ These effects were explained from the mTOR perspective, revealing a rationale to combine rapamycin and metformin. ${ }^{164}$ Two agents may even cancel each other side effects. For example, whereas metformin can increase lactate production, rapamycin decreases it. ${ }^{165}$ Metformin also prevents cancer and other age-related diseases in humans. ${ }^{166-174}$ 
Aspirin, an anti-inflammatory agent, decreases pro-inflammation, a marker of senescence, as well as inhibits hyperfunctions of blood platelets and endothelial cells. ${ }^{133,175,176}$ There is increasing evidence that aspirin is beneficial in the prevention of multiple age-related diseases and their complications. ${ }^{177-184}$ Aspirin increases life span of genetically heterogeneous male mice ${ }^{179}$ and even in the worm Caenorhabditis elegans. ${ }^{185}$

Angiotensin II activates mTOR pathway ${ }^{186}$ and is involved in aging and age-related diseases in mammals. ${ }^{187,188}$ Disruption of the Ang II type 1 receptor promotes longevity in mice. At 29 months, when all wild-type animals died, 85\% mice lacking the receptor were still alive. These remaining AT1 - / - mice lived for an additional 7 months, with life span $26 \%$ longer than controls. ${ }^{189}$ Angiotensin II receptor blockers (ARB) (Valsartan, Telmisartan, Losartan) as well as angiotensin-converting enzyme inhibitors (Captopril, Lisinopril, Enalapril, Ramipril) are widely used as therapy for hypertension. Long-term angiotensin-converting enzyme inhibition or ARB doubles life span of hypertensive rats. ${ }^{190,191}$ In healthy (normal blood pressure) rats, long-term enalapril treatment decreases body weight gain and prolonged life span. ${ }^{192}$ Long-term use of ARBs is associated with a lower incidence of cancer occurrence, thereby suggesting that ARBs may prevent cancer development. ${ }^{193}$

Propranolol, a non-selective beta-adrenergic blocker, is widely used to treat hypertension and ischemic heart disease. In addition, propranolol prevents cancer ${ }^{194-197}$ and hepatic steatosis. ${ }^{198}$ Also, berberine and statins ${ }^{199}$ can be included into the anti-aging formula, especially given that statins prevent rapamycin-induced dyslipidemia. ${ }^{23}$

\section{Conclusion: Lessons Learned from Koschei}

The creators of fairy tales noticed that the extraordinary longevity is associated with thinness, whereas obese people do not live long. It is not a coincidence that another character of Slavic tales, Baba Yaga the bony leg (kostianaia noga), was extremely old and thin. She cooked potion (зелье), an antiaging mixture, for Koschei and herself. Now we can compose this mixture by using available drugs. The cornerstone of the formula is a rapalog such as rapamycin. Yet, gerontologists claim that rapamycin cannot be used in humans because of its terrible side effects. This modern tale about side effects of rapamycin might surprise physicians, who have prescribed rapamycin, everalimus to millions of patients worldwide. But practicing doctors do not read basic science papers. Why this misinformation circulates among gerontologists and other basic scientists. May be because Koschei and Baba Yaga were evil and had long curly hair (side effects). Or there are other reasons. I will discuss this in forthcoming article 'Does mankind deserve rapamycin'.

\section{Conflict of Interest}

The author declares no conflict of interest.

1. Chang GR, Chiu YS, Wu YY, Chen WY, Liao JW, Chao TH et al. Rapamycin protects against high fat diet-induced obesity in C57BL/6 J mice. J Pharmacol Sci 2009; 109: 496-503.

2. Chang GR, Wu YY, Chiu YS, Chen WY, Liao JW, Hsu HM et al. Long-term administration of rapamycin reduces adiposity, but impairs glucose tolerance in high-fat diet-fed KK/HIJ mice. Basic Clin Pharmacol Toxicol 2009; 105: 188-198.
3. Leontieva OV, Paszkiewicz G, Demidenko ZN, Blagosklonny MV. Resveratrol potentiates rapamycin to prevent hyperinsulinemia and obesity in male mice on high fat diet. Cell Death Dis 2013; 4: e472.

4. Makki K, Taront S, Molendi-Coste O, Bouchaert E, Neve B, Eury E et al. Beneficial metabolic effects of rapamycin are associated with enhanced regulatory cells in dietinduced obese mice. PLoS One 2014; 9: e92684.

5. Rovira J, Marcelo Arellano E, Burke JT, Brault Y, Moya-Rull D, Bañón-Maneus E et al. Effect of mTOR inhibitor on body weight: from an experimental rat model to human transplant patients. Transpl Int 2008; 21: 992-998.

6. Houde VP, Brule S, Festuccia WT, Blanchard PG, Bellmann K, Deshaies Y et al. Chronic rapamycin treatment causes glucose intolerance and hyperlipidemia by upregulating hepatic gluconeogenesis and impairing lipid deposition in adipose tissue. Diabetes 2010; 59: $1338-1348$.

7. Deblon N, Bourgoin L, Veyrat-Durebex C, Peyrou M, Vinciguerra M, Caillon A et al. Chronic mTOR inhibition by rapamycin induces muscle insulin resistance despite weight loss in rats. Br J Pharmacol 2012; 165: 2325-2340.

8. Diekmann F, Campistol JM, Rovira J, Budde K, Neumayer HH, Oppenheimer F et al. Treatment with sirolimus is associated with less weight gain after kidney transplantation. Transplantation 2013; 96: 480-486.

9. Morrisett JD, Abdel-Fattah G, Hoogeveen R, Mitchell E, Ballantyne CM, Pownall HJ et al. Effects of sirolimus on plasma lipids, lipoprotein levels, and fatty acid metabolism in renal transplant patients. J Lipid Res 2002; 43: 1170-1180.

10. Chakrabarti P, English T, Shi J, Smas CM, Kandror KV. Mammalian target of rapamycin complex 1 suppresses lipolysis, stimulates lipogenesis, and promotes fat storage. Diabetes 2010; 59: 775-781.

11. Yu Z, Wang R, Fok WC, Coles A, Salmon AB, Perez VI. Rapamycin and dietary restriction Induce metabolically distinctive changes in mouse liver. J Gerontol A Biol Sci Med Sci 2014; e-pub ahead of print 22 April 2014.

12. Lamming DW, Sabatini DM. A Central role for mTOR in lipid homeostasis. Cell Metab 2013; 18: 465-469.

13. Blagosklonny MV. TOR-centric view on insulin resistance and diabetic complications: perspective for endocrinologists and gerontologists. Cell Death Dis 2013; 4: e964.

14. Yeh WC, Bierer BE, McKnight SL. Rapamycin inhibits clonal expansion and adipogenic differentiation of 3T3-L1 cells. Proc Natl Acad Sci USA 1995; 92: 11086-11090.

15. Bell A, Grunder L, Sorisky A. Rapamycin inhibits human adipocyte differentiation in primary culture. Obes Res 2000; 8: 249-254.

16. Zhang HH, Huang J, Duvel K, Boback B, Wu S, Squillace RM et al. Insulin stimulates adipogenesis through the Akt-TSC2-mTORC1 pathway. PLoS One 2009; 4: e6189.

17. Blagosklonny MV. Validation of anti-aging drugs by treating age-related diseases. Aging (Albany NY) 2009; 1: 281-288.

18. Pakala R, Stabile E, Jang GJ, Clavijo L, Waksman R. Rapamycin attenuates atherosclerotic plaque progression in apolipoprotein $E$ knockout mice: inhibitory effect on monocyte chemotaxis. J Cardiovasc Pharmacol 2005; 46: 481-486.

19. Elloso MM, Azrolan N, Sehgal SN, Hsu PL, Phiel KL, Kopec CA et al. Protective effect of the immunosuppressant sirolimus against aortic atherosclerosis in apo E-deficient mice. Am J Transplant 2003; 3: 562-569.

20. Chen $W Q$, Zhong $L$, Zhang L, Ji XP, Zhang M, Zhao YX et al. Oral rapamycin attenuates inflammation and enhances stability of atherosclerotic plaques in rabbits independent of serum lipid levels. Br J Pharmacol 2009; 156: 941-951.

21. Liu Y, Diaz V, Fernandez E, Strong R, Ye L, Baur JA et al. Rapamycin-induced metabolic defects are reversible in both lean and obese mice. Aging (Albany NY) 2014; 6 742-754.

22. Fang $\mathrm{Y}$, Bartke A. Prolonged rapamycin treatment led to beneficial metabolic switch. Aging (Albany NY) 2013; 5: 328-329.

23. Legendre C, Campistol JM, Squifflet JP, Burke JTGroup. SERTS, Cardiovascular risk factors of sirolimus compared with cyclosporine: early experience from two randomized trials in renal transplantation. Transplant Proc 2003; 35: 151S-153S.

24. Kapahi P, Zid BM, Harper T, Koslover D, Sapin V, Benzer S. Regulation of lifespan in Drosophila by modulation of genes in the TOR signaling pathway. Curr Biol 2004; 14: 885-890.

25. Wullschleger S, Loewith R, Hall MN. TOR signaling in growth and metabolism. Cell 2006; 124: $471-484$.

26. Loewith R, Hall MN. Target of rapamycin (TOR) in nutrient signaling and growth control. Genetics 2011; 189: 1177-1201.

27. Howell JJ, Manning BD. mTOR couples cellular nutrient sensing to organismal metabolic homeostasis. Trends Endocrinol Metab 2011; 22: 94-102.

28. Kapahi P, Chen D, Rogers AN, Katewa SD, Li PW, Thomas EL et al. With TOR, less is more: a key role for the conserved nutrient-sensing TOR pathway in aging. Cell Metab. 2010; 11: 453-465

29. Sengupta S, Peterson TR, Sabatini DM. Regulation of the mTOR complex 1 pathway by nutrients, growth factors, and stress. Mol Cell 2010; 40: 310-322.

30. Zoncu R, Efeyan A, Sabatini DM. mTOR: from growth signal integration to cancer, diabetes and ageing. Nat Rev Mol Cell Biol 2011; 12: 21-35.

31. Duran RV, Hall MN. Glutaminolysis feeds mTORC1. Cell Cycle 2012; 11: 4107-4108.

32. Khamzina L, Veilleux A, Bergeron S, Marette A. Increased activation of the mammalian target of rapamycin pathway in liver and skeletal muscle of obese rats: possible involvement in obesity-linked insulin resistance. Endocrinology 2005; 146: 1473-1481. 
33. Bochkis IM, Shin S, Kaestner KH. Bile acid-induced inflammatory signaling in mice lacking Foxa2 in the liver leads to activation of mTOR and age-onset obesity. Mol Metab 2013; 2 : 447-456.

34. Tremblay F, Marette A. Amino acid and insulin signaling via the mTOR/p70 S6 kinase pathway. A negative feedback mechanism leading to insulin resistance in skeletal muscle cells. J Biol Chem 2001; 276: 38052-38060.

35. Um SH, Frigerio F, Watanabe M, Picard F, Joaquin M, Sticker M et al. Absence of S6K1 protects against age- and diet-induced obesity while enhancing insulin sensitivity. Nature 2004; 431: 200-205.

36. Harrington LS, Findlay GM, Lamb RF. Restraining PI3K: mTOR signalling goes back to the membrane. Trends Biochem Sci 2005; 30: 35-42.

37. Corradetti MN, Guan KL. Upstream of the mammalian target of rapamycin: do all roads pass through mTOR? Oncogene 2006; 25: 6347-6360.

38. Yu Y, Yoon SO, Poulogiannis G, Yang Q, Ma XM, Villen J et al. Phosphoproteomic analysis identifies Grb10 as an mTORC1 substrate that negatively regulates insulin signaling Science 2011; 332: 1322-1326.

39. Hsu PP, Kang SA, Rameseder J, Zhang Y, Ottina KA, Lim D et al. The mTOR-regulated phosphoproteome reveals a mechanism of mTORC1-mediated inhibition of growth factor signaling. Science 2011; 332: 1317-1322.

40. Einstein FH, Fishman S, Bauman J, Thompson RF, Huffman DM, Atzmon G et al. Enhanced activation of a 'nutrient-sensing' pathway with age contributes to insulin resistance. Faseb J 2008; 22: 3450-3457.

41. Mordier S, Iynedjian PB. Activation of mammalian target of rapamycin complex 1 and insulin resistance induced by palmitate in hepatocytes. Biochem Biophys Res Commun 2007; 362: 206-211.

42. Saha AK, Xu XJ, Balon TW, Brandon A, Kraegen EW, Ruderman NB. Insulin resistance due to nutrient excess: is it a consequence of AMPK downregulation? Cell Cycle 2011; 10 : 3447-3451.

43. Shah OJ, Wang Z, Hunter T. Inappropriate activation of the TSC/Rheb/mTOR/S6K cassette induces IRS1/2 depletion, insulin resistance, and cell survival deficiencies. Curr Biol 2004; 14: $1650-1656$.

44. Tremblay F, Krebs M, Dombrowski L, Brehm A, Bernroider E, Roth E et al. Overactivation of S6 kinase 1 as a cause of human insulin resistance during increased amino acid availability. Diabetes 2005; 54: 2674-2684.

45. Luong N, Davies CR, Wessells RJ, Graham SM, King MT, Veech R et al. Activated FOXOmediated insulin resistance is blocked by reduction of TOR activity. Cell Metab 2006; 4 133-142

46. Krebs M, Brunmair B, Brehm A, Artwohl M, Szendroedi J, Nowotny P et al. The Mammalian target of rapamycin pathway regulates nutrient-sensitive glucose uptake in man. Diabetes 2007; 56: 1600-1607.

47. Shaw RJ, Lamia KA, Vasquez D, Koo SH, Bardeesy N, Depinho RA et al. The kinase LKB1 mediates glucose homeostasis in liver and therapeutic effects of metformin. Science 2005; 310: $1642-1646$

48. Tzatsos A, Kandror KV. Nutrients suppress phosphatidylinositol 3-kinase/Akt signaling via raptor-dependent mTOR-mediated insulin receptor substrate 1 phosphorylation. Mol Cell Biol 2006; 26: 63-76.

49. Vodenik B, Rovira J, Campistol JM. Mammalian target of rapamycin and diabetes: what does the current evidence tell us? Transplant Proc 2009; 41: S31-S38.

50. Daquinag AC, Tseng C, Salameh A, Zhang Y, Amaya-Manzanares F, Dadbin A et al. Depletion of white adipocyte progenitors induces beige adipocyte differentiation and suppresses obesity development. Cell Death Differ 2014; e-pub ahead of print 24 October 2014; doi:10.1038/cdd.2014.148

51. Molchadsky A, Ezra O, Amendola PG, Krantz D, Kogan-Sakin I, Buganim Y et al. p53 is required for brown adipogenic differentiation and has a protective role against diet-induced obesity. Cell Death Differ 2013; 20: 774-783.

52. Nguyen MT, Csermely P, Soti C. Hsp90 chaperones PPARgamma and regulates differentiation and survival of 3T3-L1 adipocytes. Cell Death Differ 2013; 20: 1654-1663.

53. Nisoli E, Cardile A, Bulbarelli A, Tedesco L, Bracale R, Cozzi V et al. White adipocytes are less prone to apoptotic stimuli than brown adipocytes in rodent. Cell Death Differ 2006; 13 2154-2156.

54. Barth JM, Szabad J, Hafen E, Kohler K. Autophagy in Drosophila ovaries is induced by starvation and is required for oogenesis. Cell Death Differ 2011; 18: 915-924.

55. Cai D, Liu T. Inflammatory cause of metabolic syndrome via brain stress and NF-kappaB. Aging (Albany NY) 2012; 4: 98-115

56. Fabre O, Breuker C, Amouzou C, Salehzada T, Kitzmann M, Mercier J et al. Defects in TLR3 expression and RNase $L$ activation lead to decreased MnSOD expression and insulin resistance in muscle cells of obese people. Cell Death Dis 2014; 5: e1136.

57. Fabre O, Salehzada T, Lambert K, Boo Seok Y, Zhou A, Mercier J et al. RNase L controls terminal adipocyte differentiation, lipids storage and insulin sensitivity via CHOP10 mRNA regulation. Cell Death Differ 2012; 19: 1470-1481.

58. Perry RJ, Shulman Gl. Treating fatty liver and insulin resistance. Aging (Albany NY) 2013; 5 791-792.

59. Galbo T, Perry RJ, Nishimura E, Samuel VT, Quistorff B, Shulman GI. PP2A inhibition results in hepatic insulin resistance despite Akt2 activation. Aging (Albany NY) 2013; 5: 770-781.

60. Galbo T, Shulman GI. Lipid-induced hepatic insulin resistance. Aging (Albany NY) 2013; 5 582-583.
61. Rogers NH, Smith RG. Brown-to-white transition in subcutaneous fat: linking aging and disease. Aging (Albany NY) 2012; 4: 728-729.

62. Leibowitz G, Cerasi E, Ketzinel-Gilad M. The role of $\mathrm{mTOR}$ in the adaptation and failure of beta-cells in type 2 diabetes. Diabetes Obes Metab 2008; 10: 157-169.

63. Shigeyama Y, Kobayashi T, Kido Y, Hashimoto N, Asahara S, Matsuda T et al. Biphasic response of pancreatic beta-cell mass to ablation of tuberous sclerosis complex 2 in mice. Mol Cell Biol 2008; 28: 2971-2979.

64. Lamming DW, Ye L, Katajisto P, Goncalves MD, Saitoh M, Stevens DM et al. Rapamycininduced insulin resistance is mediated by mTORC2 loss and uncoupled from longevity. Science 2012; 335: 1638-1643.

65. Lamming DW, Ye L, Astle CM, Baur JA, Sabatini DM, Harrison DE. Young and old genetically heterogeneous HET3 mice on a rapamycin diet are glucose intolerant but insulin sensitive. Aging Cell 2013; 12: 712-718.

66. Blagosklonny MV. Rapamycin-induced glucose intolerance: hunger or starvation diabetes. Cell Cycle 2011; 10: 4217-4224

67. Blagosklonny MV. Once again on rapamycin-induced insulin resistance and longevity: despite of or owing to. Aging (Albany NY) 2012; 4: 350-358.

68. Fontana L, Meyer TE, Klein S, Holloszy JO. Long-term calorie restriction is highly effective in reducing the risk for atherosclerosis in humans. Proc Natl Acad Sci USA 2004; 101: $6659-6663$.

69. Fontana L, Partridge L, Longo VD. Extending healthy life span-from yeast to humans. Science 2010; 328: 321-326.

70. Kennedy BK, Steffen KK, Kaeberlein M. Ruminations on dietary restriction and aging. Cell Mol Life Sci 2007; 64: 1323-1328.

71. Baur JA, Chen D, Chini EN, Chua K, Cohen HY, de Cabo R et al. Dietary restriction: standing up for sirtuins. Science 2010; 329: 1012-1013.

72. Houthoofd K, Gems D, Johnson TE, Vanfleteren JR. Dietary restriction in the nematode Caenorhabditis elegans. Interdiscip Top Gerontol 2007; 35: 98-114.

73. Ingram DK, Roth GS, Lane MA, Ottinger MA, Zou S, de Cabo R et al. The potential for dietary restriction to increase longevity in humans: extrapolation from monkey studies. Biogerontology 2006; 7: 143-148.

74. Blagosklonny MV. Calorie restriction: decelerating mTOR-driven aging from cells to organisms (including humans). Cell Cycle 2010; 9: 683-688.

75. Cava E, Fontana L. Will calorie restriction work in humans? Aging (Albany NY) 2013; 5 507-514.

76. Mercken EM, Carboneau BA, Krzysik-Walker SM, de Cabo R. Of mice and men: the benefits of caloric restriction, exercise, and mimetics. Ageing Res Rev 2012; 11: 390-398.

77. Jiang N, Du G, Tobias E, Wood JG, Whitaker R, Neretti N et al. Dietary and genetic effects on age-related loss of gene silencing reveal epigenetic plasticity of chromatin repression during aging. Aging (Albany NY) 2013; 5: 813-824.

78. Partridge L, Alic N, Bjedov I, Piper MD. Ageing in Drosophila: the role of the insulin/lgf and TOR signalling network. Exp Gerontol 2011; 46: 376-381.

79. Emran S, Yang M, He X, Zandveld J, Piper MD. Target of rapamycin signalling mediates the lifespan-extending effects of dietary restriction by essential amino acid alteration. Aging (Albany NY) 2014; 6: 390-398.

80. Lettieri Barbato D, Tatulli G, Aquilano K, Ciriolo MR. FoxO1 controls lysosomal acid lipase in adipocytes: implication of lipophagy during nutrient restriction and metformin treatment. Cell Death Dis 2013; 4: e861.

81. Morselli E, Maiuri MC, Markaki M, Megalou E, Pasparaki A, Palikaras K et al. Caloric restriction and resveratrol promote longevity through the Sirtuin-1-dependent induction of autophagy. Cell Death Dis 2010; 1: e10.

82. Berrigan D, Perkins SN, Haines DC, Hursting SD. Adult-onset calorie restriction and fasting delay spontaneous tumorigenesis in p53-deficient mice. Carcinogenesis 2002; 23: 817-822.

83. Lefevre M, Redman LM, Heilbronn LK, Smith JV, Martin CK, Rood JC et al. Caloric restriction alone and with exercise improves CVD risk in healthy non-obese individuals. Atherosclerosis 2008; 203: 206-213.

84. Colman RJ, Beasley TM, Allison DB, Weindruch R. Attenuation of sarcopenia by dietary restriction in rhesus monkeys. J Gerontol A Biol Sci Med Sci 2008; 63: 556-559.

85. Fontana L, Klein S, Holloszy J. Effects of long-term calorie restriction and endurance exercise on glucose tolerance, insulin action, and adipokine production. Age (Dordr) 2010; 32: $97-108$.

86. Ye L, Widlund AL, Sims CA, Lamming DW, Guan Y, Davis JG et al. Rapamycin doses sufficient to extend lifespan do not compromise muscle mitochondrial content or endurance. Aging (Albany NY) 2013; 5: 539-550.

87. Leontieva OV, Paszkiewicz GM, Blagosklonny MV. Weekly administration of rapamycin improves survival and biomarkers in obese male mice on high-fat diet. Aging Cell. 2014; 13: 616-622.

88. Anisimov VN, Zabezhinski MA, Popovich IG, Piskunova TS, Semenchenko AV, Tyndyk ML et al. Rapamycin extends maximal lifespan in cancer-prone mice. Am J Pathol 2010; 176: 2092-2097.

89. Anisimov VN, Zabezhinski MA, Popovich IG, Piskunova TS, Semenchenko AV, Tyndyk ML et al. Rapamycin increases lifespan and inhibits spontaneous tumorigenesis in inbred female mice. Cell Cycle. 2011; 10: 4230-4236. 
90. Popovich IG, Anisimov VN, Zabezhinski MA, Semenchenko AV, Tyndyk ML, Yurova MN et al. Lifespan extension and cancer prevention in HER-2/neu transgenic mice treated with low intermittent doses of rapamycin. Cancer Biol Ther 2014; 15: 586-592.

91. Comas M, Toshkov I, Kuropatwinski KK, Chernova OB, Polinsky A, Blagosklonny MV et al. New nanoformulation of rapamycin Rapatar extends lifespan in homozygous p53 - / mice by delaying carcinogenesis. Aging (Albany NY) 2012; 4: 715-722.

92. Kondratov RV, Kondratova AA. Rapamycin in preventive (very low) doses. Aging (Albany NY) 2014; 6: 158-159.

93. Khapre RV, Kondratova AA, Patel S, Dubrovsky Y, Wrobel M, Antoch MP et al. BMAL1dependent regulation of the mTOR signaling pathway delays aging. Aging (Albany NY) 2014; 6: 48-57.

94. Ye L, Varamini B, Lamming DW, Sabatini DM, Baur JA. Rapamycin has a biphasic effect on insulin sensitivity in $\mathrm{C} 2 \mathrm{C} 12$ myotubes due to sequential disruption of mTORC1 and mTORC2. Front Genet 2012; 3: 177.

95. Leontieva OV, Demidenko ZN, Blagosklonny MV. Rapamycin reverses insulin resistance (IR) in high-glucose medium without causing IR in normoglycemic medium. Cell Death Dis 2014; 5: e1214.

96. Law BK Rapamycin: an anti-cancer immunosuppressant? Crit Rev Oncol Hematol 2005; 56: $47-60$.

97. Campistol JM, Eris J, Oberbauer R, Friend P, Hutchison B, Morales JM et al. Sirolimus therapy after early cyclosporine withdrawal reduces the risk for cancer in adult renal transplantation. J Am Soc Nephrol 2006; 17: 581-589.

98. Blagosklonny MV. Prevention of cancer by inhibiting aging. Cancer Biol Ther 2008; 7: 1520-1524.

99. Paoletti E, Cannella G. Regression of left ventricular hypertrophy in kidney transplant recipients: the potential role for inhibition of mammalian target of rapamycin. Transplant Proc 42: S41-S43.

100. Shi WY, Xiao D, Wang L, Dong LH, Yan ZX, Shen ZX et al. Therapeutic metformin/AMPK activation blocked lymphoma cell growth via inhibition of mTOR pathway and induction of autophagy. Cell Death Dis 2012; 3: e275.

101. Airiau K, Mahon FX, Josselin M, Jeanneteau M, Belloc F. PI3K/mTOR pathway inhibitors sensitize chronic myeloid leukemia stem cells to nilotinib and restore the response of progenitors to nilotinib in the presence of stem cell factor. Cell Death Dis 2013; 4: e827.

102. Chang L, Graham PH, Hao J, Ni J, Bucci J, Cozzi PJ et al. PI3K/Akt/mTOR pathway inhibitors enhance radiosensitivity in radioresistant prostate cancer cells through inducing apoptosis, reducing autophagy, suppressing NHEJ and HR repair pathways. Cell Death Dis 2014; 5: e1437.

103. Ng TL, Leprivier G, Robertson MD, Chow C, Martin MJ, Laderoute KR et al. The AMPK stress response pathway mediates anoikis resistance through inhibition of mTOR and suppression of protein synthesis. Cell Death Differ 2011; 19: 501-510.

104. Chang L, Graham PH, Hao J, Ni J, Bucci J, Cozzi PJ et al. Acquisition of epithelialmesenchymal transition and cancer stem cell phenotypes is associated with activation of the PI3K/Akt/mTOR pathway in prostate cancer radioresistance. Cell Death Dis 2013; 4: e875.

105. Francipane MG, Lagasse E. Selective targeting of human colon cancer stem-like cells by the mTOR inhibitor Torin-1. Oncotarget 2013; 4: 1948-1962.

106. Cufi S, Corominas-Faja B, Lopez-Bonet E, Bonavia R, Pernas S, Lopez IA et al. Dietary restriction-resistant human tumors harboring the PIK3CA-activating mutation H1047R are sensitive to metformin. Oncotarget 2013; 4: 1484-1495.

107. Reikvam H, Nepstad I, Bruserud O, Hatfield KJ. Pharmacological targeting of the $\mathrm{PI} 3 \mathrm{~K} / \mathrm{mTOR}$ pathway alters the release of angioregulatory mediators both from primary human acute myeloid leukemia cells and their neighboring stromal cells. Oncotarget 2013; 4: 830-843.

108. Chiarini F, Lonetti A, Teti G, Orsini E, Bressanin D, Cappellini A et al. A combination of temsirolimus, an allosteric mTOR inhibitor, with clofarabine as a new therapeutic option for patients with acute myeloid leukemia. Oncotarget 2012; 3: 1615-1628.

109. Martelli AM, Chiarini F, Evangelisti C, Cappellini A, Buontempo F, Bressanin D et al. Two hits are better than one: targeting both phosphatidylinositol 3-kinase and mammalian target of rapamycin as a therapeutic strategy for acute leukemia treatment. Oncotarget 2012; 3 : 371-394.

110. Blagosklonny MV, Hall MN. Growth and aging: a common molecular mechanism. Aging (Albany NY) 2009; 1: 357-362.

111. Blagosklonny MV. Revisiting the antagonistic pleiotropy theory of aging: TOR-driven program and quasi-program. Cell Cycle. 2010; 9: 3151-3156.

112. Blagosklonny MV. Aging is not programmed: genetic pseudo-program is a shadow of developmental growth. Cell Cycle. 2013; 12: 3736-3742.

113. Harrison DE, Strong R, Sharp ZD, Nelson JF, Astle CM, Flurkey K et al. Rapamycin fed late in life extends lifespan in genetically heterogenous mice. Nature 2009; 460: 392-396.

114. Spong A, Bartke A. Rapamycin slows aging in mice. Cell Cycle 2012; 11: 845.

115. Wilkinson JE, Burmeister L, Brooks SV, Chan CC, Friedline S, Harrison DE et al. Rapamycin slows aging in mice. Aging Cell. 2012; 11: 675-682.

116. Blagosklonny MV. Rapamycin extends life- and health span because it slows aging. Aging (Albany NY) 2013; 5: 592-598.

117. Zhang Y, Bokov A, Gelfond J, Soto V, Ikeno Y, Hubbard G et al. Rapamycin extends life and health in C57BL/6 mice. J Gerontol A Biol Sci Med Sci 2013; 69: 119-130.
118. Robida-Stubbs S, Glover-Cutter K, Lamming DW, Mizunuma M, Narasimhan SD, Neumann-Haefelin $\mathrm{E}$ et al. TOR signaling and rapamycin influence longevity by regulating SKN-1/Nrf and DAF-16/FoxO. Cell Metab 2012; 15: 713-724.

119. Blagosklonny MV. Answering the ultimate question 'what is the proximal cause of aging?'. Aging (Albany NY) 2012; 4: 861-877.

120. Fok WC, Chen Y, Bokov A, Zhang Y, Salmon AB, Diaz V et al. Mice fed rapamycin have an increase in lifespan associated with major changes in the liver transcriptome. PLoS One 2013; 9: e83988.

121. Hinojosa CA, Mgbemena V, Van Roekel S, Austad SN, Miller RA, Bose S et al. Enteric-delivered rapamycin enhances resistance of aged mice to pneumococcal pneumonia through reduced cellular senescence. Exp Gerontol 2012; 47: 958-965.

122. Leontieva OV, Demidenko ZN, Blagosklonny MV. S6K in geroconversion. Cell Cycle 2013; 12: 3249-3252.

123. Leontieva OV, Blagosklonny MV. CDK4/6-inhibiting drug substitutes for p21 and p16 in senescence: duration of cell cycle arrest and MTOR activity determine geroconversion. Cell Cycle 2013; 12: 3063-3069.

124. Leontieva OV, Natarajan V, Demidenko ZN, Burdelya LG, Gudkov AV, Blagosklonny MV. Hypoxia suppresses conversion from proliferative arrest to cellular senescence. Proc Natl Acad Sci USA 2012; 109: 13314-13318.

125. Leontieva OV, Demidenko ZN, Blagosklonny MV. Contact inhibition and high cell density deactivate the mammalian target of rapamycin pathway, thus suppressing the senescence program. Proc Natl Acad Sci USA 2014; 111: 8832-8837.

126. Leontieva OV, Demidenk ZN, Blagosklonny MV. MEK drives cyclin D1 hyperelevation during geroconversion. Cell Deth Diff 2013; 20: 1241-1249.

127. Iglesias-Bartolome R, Patel V, Cotrim A, Leelahavanichkul K, Molinolo AA, Mitchell JB et al. mTOR inhibition prevents epithelial stem cell senescence and protects from radiationinduced mucositis. Cell Stem Cell 2012; 11: 401-414.

128. Kolesnichenko M, Hong L, Liao R, Vogt PK, Sun P. Attenuation of TORC1 signaling delays replicative and oncogenic RAS-induced senescence. Cell Cycle 2012; 11: 2391-2401.

129. Mercier I, Camacho J, Titchen K, Gonzales DM, Quann K, Bryant KG et al. Caveolin-1 and accelerated host aging in the breast tumor microenvironment: chemoprevention with rapamycin, an mTOR inhibitor and anti-aging drug. Am J Pathol 2012; 181: 278-293.

130. Luo Y, Li L, Zou P, Wang J, Shao L, Zhou D et al. Rapamycin enhances long-term hematopoietic reconstitution of ex vivo expanded mouse hematopoietic stem cells by inhibiting senescence. Transplantation 2014; 97: 20-29.

131. Rodier F, Munoz DP, Teachenor R, Chu V, Le O, Bhaumik D et al. DNA-SCARS: distinct nuclear structures that sustain damage-induced senescence growth arrest and inflammatory cytokine secretion. J Cell Sci 2011; 124: 68-81.

132. Tchkonia T, Zhu Y, van Deursen J, Campisi J, Kirkland JL. Cellular senescence and the senescent secretory phenotype: therapeutic opportunities. J Clin Invest 2013; 123: 966-972.

133. Halicka HD, Zhao H, Li J, Lee YS, Hsieh TC, Wu JM et al. Potential anti-aging agents suppress the level of constitutive mTOR- and DNA damage- signaling. Aging (Albany NY) 2012; 4: 952-965.

134. Narita M, Young AR, Arakawa S, Samarajiwa SA, Nakashima T, Yoshida S et al. Spatial coupling of mTOR and autophagy augments secretory phenotypes. Science 2011; 332: 966-970.

135. Pani G. From growing to secreting: new roles for mTOR in aging cells. Cell Cycle 2011; 10: 2450-2453.

136. Blagosklonny MV. Tumor suppression by p53 without apoptosis and senescence: conundrum or rapalog-like gerosuppression? Aging (Albany NY) 2012; 4: 450-455.

137. Dann SG, Selvaraj A, Thomas G. mTOR Complex1-S6K1 signaling: at the crossroads of obesity, diabetes and cancer. Trends Mol Med 2007; 13: 252-259.

138. Cornu M, Albert V, Hall MN. mTOR in aging, metabolism, and cancer. Curr Opin Genet Dev 2013; 23: 53-62.

139. Mabuchi S, Altomare DA, Connolly DC, Klein-Szanto A, Litwin S, Hoelzle MK et al. RAD001 (Everolimus) delays tumor onset and progression in a transgenic mouse model of ovarian cancer. Cancer Res. 2007; 67: 2408-2413.

140. Granville CA, Warfel N, Tsurutani J, Hollander MC, Robertson M, Fox SD et al. Identification of a highly effective rapamycin schedule that markedly reduces the size, multiplicity, and phenotypic progression of tobacco carcinogen-induced murine lung tumors. Clin Cancer Res 2007; 13: 2281-2289.

141. Komarova EA, Antoch MP, Novototskaya LR, Chernova OB, Paszkiewicz G, Leontieva OV et al. Rapamycin extends lifespan and delays tumorigenesis in heterozygous p53 +/ - mice. Aging (Albany NY) 2012; 4: 709-714.

142. Donehower LA. Rapamycin as longevity enhancer and cancer preventative agent in the context of p53 deficiency. Aging (Albany NY) 2012; 4: 660-661.

143. Livi CB, Hardman RL, Christy BA, Dodds SG, Jones D, Williams C et al. Rapamycin extends life span of Rb1+/- mice by inhibiting neuroendocrine tumors. Aging (Albany NY) 2013; 5: 100-110.

144. Blagosklonny MV. Rapalogs in cancer prevention: anti-aging or anticancer? Cancer Biol Ther 2012; 13: 1349-1354

145. Blagosklonny MV. Immunosuppressants in cancer prevention and therapy. Oncoimmunology 2013; 2: e26961.

146. Selman C, Partridge L. A double whammy for aging? Rapamycin extends lifespan and inhibits cancer in inbred female mice. Cell Cycle 2012; 11: 17-18. 
147. Blagosklonny MV. Prospective treatment of age-related diseases by slowing down aging Am J Pathol 2012; 181: 1142-1146.

148. Tsang CK, Qi H, Liu LF. and Zheng XFS. Targeting mammalian target of rapamycin (mTOR) for health and diseases. Drug Disc Today 2007; 12: 112-124.

149. Zheng XF. Chemoprevention of age-related macular regeneration (AMD) with rapamycin. Aging (Albany NY) 2012; 4: 375-376.

150. Dazert E, Hall MN. mTOR signaling in disease. Curr Opin Cell Biol 2011; 23: 744-755.

151. Johnson SC, Rabinovitch PS, Kaeberlein M. mTOR is a key modulator of ageing and agerelated disease. Nature 2013; 493: 338-345.

152. Flynn JM, O'Leary MN, Zambataro CA, Academia EC, Presley MP, Garrett BJ et al. Late life rapamycin treatment reverses age-related heart dysfunction. Aging Cell 2013; 12: 851-862.

153. Johnson SC, Yanos ME, Kayser EB, Quintana A, Sangesland M, Castanza A et al. mTOR inhibition alleviates mitochondrial disease in a mouse model of Leigh syndrome. Science 2013; 342: 1524-1528.

154. Glynn EL, Lujan HL, Kramer VJ, Drummond MJ, DiCarlo SE, Rasmussen BB. A chronic increase in physical activity inhibits fed-state mTOR/S6K1 signaling and reduces IRS-1 serine phosphorylation in rat skeletal muscle. Appl Physiol Nutr Metab 2008; 33: 93-101.

155. Dilman VM, Berstein LM, Zabezhinski MA, Alexandrov VA, Bobrov JF, Pliss GB. Inhibition of DMBA-induced carcinogenesis by phenformin in the mammary gland of rats. Arch Geschwulstforsch 1978; 48: 1-8.

156. Dilman VM, Anisimov VN. Effect of treatment with phenformin, diphenylhydantoin or L-dopa on life span and tumour incidence in C3H/Sn mice. Gerontology 1980; 26: 241-246.

157. Anisimov VN, Berstein LM, Egormin PA, Piskunova TS, Popovich IG, Zabezhinski MA et al. Effect of metformin on life span and on the development of spontaneous mammary tumors in HER-2/neu transgenic mice. Exp Gerontol 2005; 40: 685-693.

158. Anisimov VN, Egormin PA, Bershtein LM, Zabezhinskii MA, Piskunova TS, Popovich IG et al. Metformin decelerates aging and development of mammary tumors in HER-2/neu transgenic mice. Bull Exp Biol Med 2005; 139: 721-723.

159. Anisimov VN, Berstein LM, Egormin PA, Piskunova TS, Popovich IG, Zabezhinski MA et al. Metformin slows down aging and extends life span of female SHR mice. Cell Cycle 2008; 7 2769-2773.

160. Martin-Montalvo A, Mercken EM, Mitchell SJ, Palacios HH, Mote PL, Scheibye-Knudsen M et al. Metformin improves healthspan and lifespan in mice. Nat Commun 2013; 4: 2192.

161. Moiseeva O, Deschenes-Simard X, Pollak M, Ferbeyre G. Metformin, aging and cancer. Aging (Albany NY) 2013; 5: 330-331

162. Anisimov VN. Metformin: do we finally have an anti-aging drug? Cell Cycle 2013; 12 3483-3489.

163. Tomic T, Botton T, Cerezo M, Robert G, Luciano F, Puissant A et al. Metformin inhibits melanoma development through autophagy and apoptosis mechanisms. Cell Death Dis 2011; 2: e199.

164. Blagosklonny MV. Aging and immortality: quasi-programmed senescence and its pharmacologic inhibition. Cell Cycle 2006; 5: 2087-2102.

165. Leontieva OV, Blagosklonny MV. M(o)TOR of pseudo-hypoxic state in aging: rapamycin to the rescue. Cell Cycle 2014; 13: 509-515.

166. Evans JM, Donnelly LA, Emslie-Smith AM, Alessi DR, Morris AD. Metformin and reduced risk of cancer in diabetic patients. BMJ 2005; 330: 1304-1305.

167. Koch L. Cancer: long-term use of metformin could protect against breast cancer. Nat Rev Endocrinol 2010; 6: 356

168. Libby G, Donnelly LA, Donnan PT, Alessi DR, Morris AD, Evans JM. New users of metformin are at low risk of incident cancer: a cohort study among people with type 2 diabetes. Diabetes Care 2009; 32: 1620-1625.

169. Berstein LM. Modern approach to metabolic rehabilitation of cancer patients: biguanides (phenformin and metformin) and beyond. Future Oncol 2010; 6: 1313-1323.

170. Memmott RM, Mercado JR, Maier CR, Kawabata S, Fox SD, Dennis PA. Metformin prevents tobacco carcinogen-induced lung tumorigenesis. Cancer Prev Res (Phila) 2010; 3: 1066-1076.

171. Gosmanova EO, Canada RB, Mangold TA, Rawls WN, Wall BM. Effect of metformincontaining antidiabetic regimens on all-cause mortality in veterans with type 2 diabetes mellitus. Am J Med Sci 2008; 336: 241-247.

172. Ng TP, Feng L, Yap KB, Lee TS, Tan CH, Winblad B. Long-term metformin usage and cognitive function among older adults with diabetes. J Alzheimers Dis 2014; 41: 61-68.

173. Pollak MN. Investigating metformin for cancer prevention and treatment: the end of the beginning. Cancer Discov 2012; 2: 778-790.

174. Zhang ZJ, Zheng ZJ, Kan H, Song Y, Cui W, Zhao G et al. Reduced risk of colorectal cancer with metformin therapy in patients with type 2 diabetes: a meta-analysis. Diabetes Care 2011; 34: 2323-2328

175. Bulckaen H, Prevost G, Boulanger E, Robitaille G, Roquet V, Gaxatte C et al. Low-dose aspirin prevents age-related endothelial dysfunction in a mouse model of physiological aging. Am J Physiol Heart Circ Physiol 2008; 294: H1562-H1570.

176. Phillips $T$, Leeuwenburgh $C$. Lifelong aspirin supplementation as a means to extending life span. Rejuvenation Res 2004; 7: 243-251.

177. Burn J, Gerdes AM, Macrae F, Mecklin JP, Moeslein G, Olschwang S et al. Long-term effect of aspirin on cancer risk in carriers of hereditary colorectal cancer: an analysis from the CAPP2 randomised controlled trial. Lancet 2011; 378: 2081-2087.
178. Din FV, Valanciute A, Houde VP, Zibrova D, Green KA, Sakamoto K et al. Aspirin inhibits mTOR signaling, activates AMP-activated protein kinase, and induces autophagy in colorectal cancer cells. Gastroenterology 2012; 142: 1504-1515 e1503.

179. Strong R, Miller RA, Astle CM, Floyd RA, Flurkey K, Hensley KL et al. Nordihydroguaiaretic acid and aspirin increase lifespan of genetically heterogeneous male mice. Aging Cell 2008; 7: $641-650$.

180. Renna NF, Vazquez MA, Lama MC, Gonzalez ES, Miatello RM. Effect of chronic aspirin administration on an experimental model of metabolic syndrome. Clin Exp Pharmacol Physiol 2009; 36: 162-168.

181. Chang ET, Froslev T, Sorensen HT, Pedersen L. A nationwide study of aspirin, other nonsteroidal anti-inflammatory drugs, and Hodgkin lymphoma risk in Denmark. $\mathrm{Br} \mathrm{J}$ Cancer 2011; 105: 1776-1782.

182. Flossmann E, Rothwell PM. Effect of aspirin on long-term risk of colorectal cancer: consistent evidence from randomised and observational studies. Lancet 2007; 369: 1603-1613.

183. Grau MV, Sandler RS, McKeown-Eyssen G, Bresalier RS, Haile RW, Barry EL et al. Nonsteroidal anti-inflammatory drug use after 3 years of aspirin use and colorectal adenoma risk: observational follow-up of a randomized study. J Natl Cancer Inst 2009; 101: 267-276.

184. Karnezis T, Shayan R, Fox S, Achen MG, Stacker SA. The connection between lymphangiogenic signalling and prostaglandin biology: a missing link in the metastatic pathway. Oncotarget 2012; 3: 893-906.

185. Wan QL, Zheng SQ, Wu GS, Luo HR. Aspirin extends the lifespan of Caenorhabditis elegans via AMPK and DAF-16/FOXO in dietary restriction pathway. Exp Gerontol 2013; 48: 499-506.

186. Eguchi S, Iwasaki H, Ueno H, Frank GD, Motley ED, Eguchi $\mathrm{K}$ et al. Intracellular signaling of angiotensin II-induced p70 S6 kinase phosphorylation at Ser(411) in vascular smooth muscle cells. Possible requirement of epidermal growth factor receptor, Ras, extracellular signal-regulated kinase, and Akt. J Biol Chem 1999; 274: 36843-36851.

187. Basso N, Paglia N, Stella I, de Cavanagh EM, Ferder L, del Rosario Lores Arnaiz M et al. Protective effect of the inhibition of the renin-angiotensin system on aging. Regul Pept 2005; 128: 247-252

188. Basso N, Cini R, Pietrelli A, Ferder L, Terragno NA, Inserra F. Protective effect of long-term angiotensin II inhibition. Am J Physiol Heart Circ Physiol 2007; 293: H1351-H1358.

189. Benigni A, Corna D, Zoja C, Sonzogni A, Latini R, Salio M et al. Disruption of the Ang II type 1 receptor promotes longevity in mice. J Clin Invest 2009; 119: 524-530.

190. Linz W, Heitsch H, Scholkens BA, Wiemer G. Long-term angiotensin II type 1 receptor blockade with fonsartan doubles lifespan of hypertensive rats. Hypertension 2000; 35: 908-913.

191. Linz W, Jessen T, Becker RH, Scholkens BA, Wiemer G. Long-term ACE inhibition doubles lifespan of hypertensive rats. Circulation 1997; 96: 3164-3172.

192. Santos EL, de Picoli Souza K, da Silva ED, Batista EC, Martins PJ, D'Almeida V et al. Long term treatment with ACE inhibitor enalapril decreases body weight gain and increases life span in rats. Biochem Pharmacol 2009; 78: 951-958.

193. Huang CC, Chan WL, Chen YC, Chen TJ, Lin SJ, Chen JW et al. Angiotensin II receptor blockers and risk of cancer in patients with systemic hypertension. Am J Cardiol 2011; 107: 1028-1033.

194. Barron TI, Connolly RM, Sharp L, Bennett K, Visvanathan K. Beta blockers and breast cancer mortality: a population- based study. J Clin Oncol 2011; 29: 2635-2644.

195. London WT, McGlynn KA. Can propranalol prevent hepatocellular carcinoma? Cancer Prev Res (Phila) 2012; 5: 989-991.

196. Powe DG, Voss MJ, Zanker KS, Habashy HO, Green AR, Ellis IO et al. Beta-blocker drug therapy reduces secondary cancer formation in breast cancer and improves cancer specific survival. Oncotarget 2010; 1: 628-638.

197. Schuller HM. Beta-adrenergic signaling, a novel target for cancer therapy? Oncotarget 2010; 1: 466-469

198. Ghosh PM, Shu ZJ, Zhu B, Lu Z, Ikeno Y, Barnes JL et al. Role of beta-adrenergic receptors in regulation of hepatic fat accumulation during aging. J Endocrinol. 213: 251-261.

199. Mehta JL, Bursac Z, Hauer-Jensen M, Fort C, Fink LM. Comparison of mortality rates in statin users versus nonstatin users in a United States veteran population. Am J Cardiol 2006; 98: 923-928.

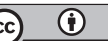

Cell Death and Disease is an open-access journal published by Nature Publishing Group. This work is licensed under a Creative Commons Attribution 4.0 International Licence. The images or other third party material in this article are included in the article's Creative Commons licence, unless indicated otherwise in the credit line; if the material is not included under the Creative Commons licence, users will need to obtain permission from the licence holder to reproduce the material. To view a copy of this licence, visit http://creativecommons.org/licenses/by/4.0 